\title{
FORENSIC INVESTIGATION OF SOW DEATHS IN THE INTENSIVE BREEDING SYSTEM
}

\author{
Nenad Stojanac ${ }^{1 \star}$, Ognjen Stevančević ${ }^{1}$, Marko R. Cincović́ ${ }^{1}$, Ivan Stančić ${ }^{1}$, \\ Aleksandar Potkonjak ${ }^{1}$, Bojan Toholj ${ }^{1}$, Vuk Vračar ${ }^{1}$ \\ ${ }^{1}$ Department of Veterinary Medicine, Faculty of Agriculture, University of Novi Sad, \\ Novi Sad, Republic of Serbia
}

\section{Abstract}

Sow mortality is a great challenge in intensive pig production worldwide. The aim of this study was to forensically examine the reason of sow death for a two-year period on two farms with intensive pig keeping, based on available data. In sows with a greater number of farrowings (over VII) greater number of deaths was found. Seasonality has an impact on sow mortality, in the summer period a larger number of sow death was found. Poor sow condition that usually occurs in the second half of lactation and after weaning, are the predisposition to the factors that lead to the sow death. On both examined farms in more than $60 \%$ of dead sows Clostridium spp. and Escherichia coli were isolated. In order to reduce the mortality of sows more attention should be paid to the older sows with a larger number of farrowings, provide better conditions in summer, cooling, and pay more attention to sows during the period from farrowing to the next insemination, respectively.

Key words: sows, death, forensics examination, risk factors

\footnotetext{
${ }^{1 *}$ e-mail: stojanac.n@gmail.com
} 


\title{
FORENZIČKO ISPITIVANJE UGINUĆA KRMAČA U INTEZIVNOM SISTEMU DRŽANJA
}

\author{
Nenad Stojanac ${ }^{1}$, Ognjen Stevančević ${ }^{1}$, Marko R. Cincović ${ }^{1}$, Ivan Stančić ${ }^{1}$, \\ Aleksandar Potkonjak ${ }^{1}$, Bojan Toholj ${ }^{1}$, Vuk Vračar ${ }^{1}$ \\ ${ }^{1}$ Poljoprivredni fakultet, Departman za veterinarsku medicinu, Novi Sad
}

\section{Kratak sadržaj}

Uginuća krmača su veliki problem u intezivnoj proizvodnji svinja širom sveta. Cilj ovog istraživanja je bio da se na dve farme sa intezivnim načinom držanja svinja forenzički ispita razlog uginuća krmača u periodu od dve godine na osnovu dostupnih podataka. Kod krmača sa većim brojem prašenja (preko VII) ustanovljen je veći broj uginuća. Sezonalitet ima uticaj na uginuće krmača, pa je u letnjem periodu ustanovljen veći broj uginuća krmača. Loša kondicija krmača, do koje najčešće dolazi u drugoj polovini laktacije i nakon zalučenja, predstavlja predispozicju za faktore koji dovode do uginuća krmača. Na obe ispitivane farme kod preko $60 \%$ uginulih krmača izolovane su bakterije Clostridium spp. i Escherichia coli. U cilju smanjenja uginuća krmača potrebno je veću pažnju posvetiti starijim krmačama sa većim brojem prašenja, u letnjem periodu obezbediti bolje uslove, rashlađivanje, odnosno više se posvetiti krmačama u periodu od prašenja pa do narednog osemenjavanja.

Ključne reči: krmače, uginuće, forenzičko ispitivanje, rizični faktori

\section{INTRODUCTION}

Deaths of sows pose major challenges in pig production worldwide, causing direct economic losses in terms of saw loss, failure or drop of expected profit from piglets and the need of purchasing new gilts. A range of factors is responsible for sow deaths. In the European Union (EU), the implementation of new legislation dated 2013 implicates loose-housing of pregnant sows, i.e. group housing in shared boxes. Such housing system increases the risk of deaths because of potential injuries that are more likely than in the system, where sows are kept in individual boxes (Anil et al., 2003; Scott et al., 2009). Numerous authors reported age, poor body condition and stomach ulcers as factors associated with increased risk of death (Koketsu, 2000; Engblom et al., 2007; Sasaki and Koketsu, 2008). Moreover, the size of the herd and seasonality could affect the rate of death in sows (Christensen et al., 1995; Koketsu, 2000). 
The pregnancy and farrowing itself also pose high risk of death (Chagnon et al., 1991). Averagely $84 \%$ of sows in intensive breeding systems are pregnant or in the stage of lactation (Koketsu, 2005), which increases the risk of death.

In the Republic of Serbia, sow-farms with intensive breeding system are often faced with the problem of sudden deaths of sows without any preceding symptoms of health disturbance (Stojanac et al., 2013). Sometimes, much greater number of sows' deaths than usual occur in a short time period of only few days, which poses a serious challenge from both aetiological and economical point of view. In that respect, the aim of this research was to perform forensic analysis and identify the possible reasons of sow deaths on two pig farms with intensive breeding system.

\section{MATERIAL AND METHODS}

The investigation encompassed two pig farms with the capacity of 2200 (Farm I) and 800 (Farm II) sows of Landrace, Yorkshire and F1 (Landrace $\mathrm{x}$ Yorkshire) breeds, and with a closed production system. At both farms, the farm management implicates weekly production system and strict application of the principle "all in/all out". The lactation period is 28 days, and after weaning, the sows were transferred into BUKARISTE. After artificial insemination, the sows remain in the bukariste for the following 30 days, when an ultrasound confirmation of the pregnancy is performed. Pregnant sows are then transferred into the cekaliste, until 110 days of gestation, and afterwards into the farrowing pens.

Forensic investigation extended over three-year period (2011-2013). In this period, 487 and 123 sows died at Farm I and Farm II, respectively. From dead animals, samples of internal organs (liver, kidney, spleen, small and large intestines, lungs, lymph nodes) were collected and subjected to standard bacteriological examination (aerobic and anaerobic isolation of the agent) (Quinn et al., 1998). Regular monitoring encompassed the control of chemical composition, microbial safety and presence of mycotoxins in sow feed by applying ELISA method.

The data sources used in this research involved the data obtained in the field, i.e. at the relevant farm, as well as official farm-records. The systematized data pertaining to all investigated parameters were evaluated using the measure of central tendency. The results were analyzed applying descriptive statistics and processed using Excel 2010. 


\section{RESULTS AND DISCUSSION}

The investigation included two farms (I and II) and extended over twoyear period (2011-2013). In this period, 487 sows died on Farm I whereas 123 sows died at Farm II. As related to the average number of sows (Table 1) the two-year rates of sow deaths were $23.21 \%$ and $16.33 \%$ on Farms I and II, respectively. The results obtained on Farm I are similar to those reported by Jensen et al., (2012), who reported death of $3 \%$ of sows in the period of three months and the results of Vestergaard et al. (2006) who established 14\% saw deaths in the period of 12 months. The rate of sow deaths on Farm II was lower as compared to the reports of aforementioned authors.

Table 1. Average number of sows according to farrowing parity in the investigated period (2011-2013)

\begin{tabular}{|c|c|c|c|c|c|}
\hline & \multicolumn{4}{|c|}{ Number of farrowings } & Total \\
\hline & I & II-VI & VII-X & $\geq$ XI & \\
\hline Farm I & 314 & 943 & 732 & 109 & 2098 \\
\hline Farm II & 125 & 497 & 109 & 22 & 753 \\
\hline
\end{tabular}

Chart 1 displays the rate of saw deaths by the number of farrowings in relation to average number of sows within given number of farrowings. High mortality rate in sows with higher number of farrowings is likely to be associated with the torsion of abdominal organs, vaginal and uterine prolapse, diseases of urinary tract and kidneys, which are often reported as characteristic for older sows (Christensen et al., 1995). According to our research, the increased mortality rate may be due to aforementioned factors, yet it was not confirmed by a patho-morphological examination. High mortality rates observed in saws that farrowed many times correspond with the results of some previous researches of other authors (Koketsu, 2000; Engblom et al., 2008). 


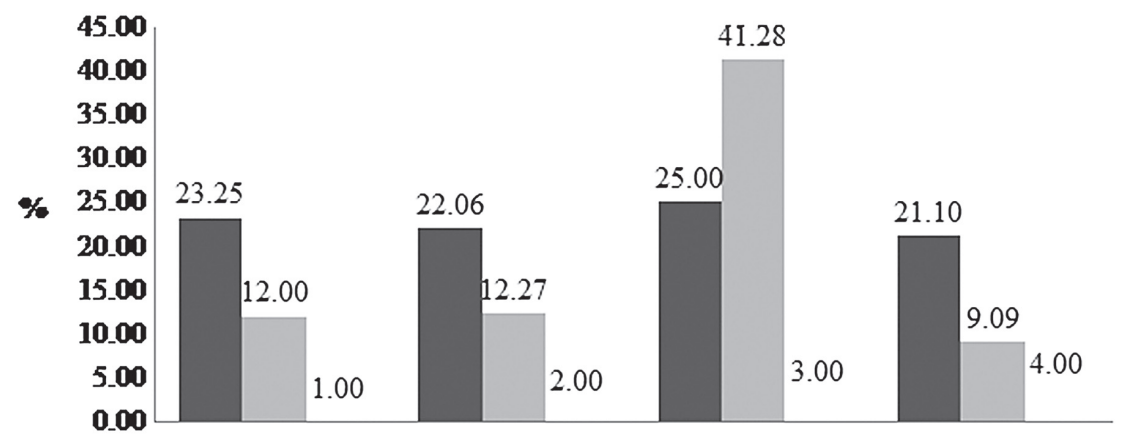

\section{q Fama I $\square$ Fama II}

Chart 1 . The percentage of dead sows according to number of farrowings

In Chart 2, the percentage of sow deaths according to seasonality is presented. The results indicated higher mortality rate in summer period (JuneSeptember) as compared to other seasons. Such result could be attributed to extremely high temperatures in Serbia during summer (over $35^{\circ} \mathrm{C}$ ) and lack of air-conditioning systems in housing facilities, thus the inside temperature might sometimes reach even $45^{\circ} \mathrm{C}$. Increased mortality rates during summer months were also reported by other authors. (Chagnon et al., 1991; Koketsu, 2000)

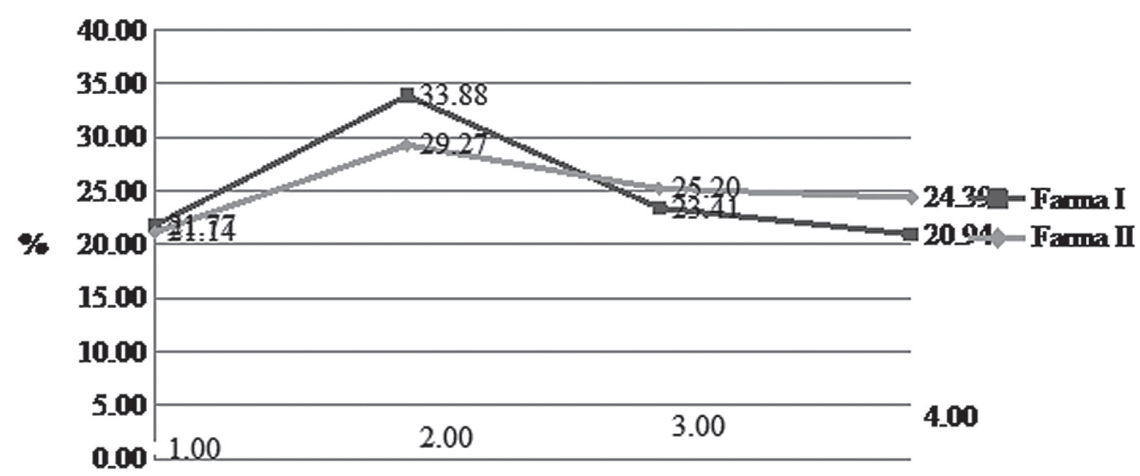

Chart 2. The percentage of dead sows according to the season of the year

Deaths of sows in relation to the stages of production cycle are presented in Chart 3. On both farms, the majority of sows died during lactation phase 
and after weaning, before the next insemination. During lactation period, the body condition of sows decreases because of negative energy balance, which may induce metabolic and reproductive disorders (Kim and Suh, 2003). Moreover, numerous authors indicated that poor body condition increases the risk of stomach ulcer ant thus increased mortality rate in sows (Davies et al., 1996; Knauer et al., 2007).

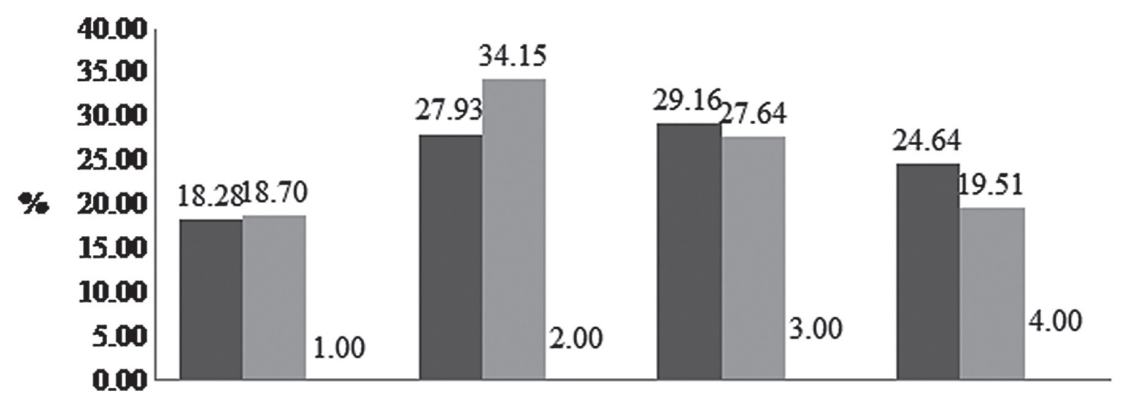

\section{घFama I $\square$ Fama II}

IWOe-interval weaning oestrus

Chart 3. Number of dead sows according to cycle phases

The samples of internal organs (liver, kidney, spleen, small and large intestines, lungs, inguinal and mesenteric lymph nodes) were obtained from 97 dead sows from Farm I and 31 saws from Farm II, and submitted for bacteriological examination. In more than $60 \%$ of dead sows from both farms, Clostridium spp. and Escherichia coli were isolated. The finding of Clostridium spp. in dead sows was reported by other authors, and the organism is identified as the causative agent of sow death (Almond and Bilkei, 2005; Friendship and Bilkei, 2007; Jandowsky et al., 2013). 
Table 2. The results of aerobic and anaerobic bacteriological examination of internal organ samples originating from dead sows

\begin{tabular}{|c|c|c|c|c|}
\hline & \multicolumn{2}{|c|}{$\begin{array}{c}\text { Number of examined } \\
\text { internal organ samples }\end{array}$} & \multicolumn{2}{c|}{$\begin{array}{c}\text { Number of positi- } \\
\text { ve samples (\%) }\end{array}$} \\
\hline & Farm I & Farm II & Farm I & Farm II \\
\hline $\begin{array}{c}\text { Streptococcus } \\
\text { zooepidemicus }\end{array}$ & 97 & 31 & $17(17.52)$ & $2(6.45)$ \\
\hline Clostridium spp. & 97 & 31 & $59(60.82)$ & $24(77.42)$ \\
\hline Escherichia coli & 97 & 31 & $65(67.01)$ & $21(67.74)$ \\
\hline
\end{tabular}

\section{CONCLUSION}

The aforementioned forensic investigation of sow death in the intensive farming system revealed important role of different factors such as age, season, cycle stage and presence of infectious agents in increased mortality of sows. Farrowing associated stress, poor body condition in the second stage of lactation and after weaning are major predisposing factors for lethal outcomes. Limitations of our research such as effects of housing system, nutrition, genetic factors and farm management are important issues in intensive sow farming. However, in spite of aforementioned limitations, this research presents a useful source of information for both veterinarians and farmers, which can substantially contribute in decreasing the rate of deaths in sows in intensive farming systems.

\section{REFERENCES}

1. Almond P.H.D., Bilkei G.: Clostridium novyi caused outdoor sow mortality in Croatia. Berliner Und Munchener Tierarztliche Wochenschrift, 118, 7-8, 296-299, 2005.

2. Anil L., Bhend K.M.G., Baidoo S.K., Morrison R., Deen J.: Comparison of injuries in sows housed in gestation stalls versus group pens with electronic sow feeders. J. Am. Vet. Med. Assoc. 223, 1334-1338, 2003.

3. Chagnon M., D'Allaire S., Drolet R.: A prospective study of sow mortality in breeding herds. Can. J. Vet. Res. 55,180-184, 1991.

4. Christensen G., Vraa-Andersen L., Mousing J.: Causes of sow mortality among sows in Danish pig herds. Vet. Rec. 137, 395-399, 1995. 
5. Davies P.R., Morrow W.E.M., Miller D.C., Deen J.: Epidemiologic study of decubital ulcers in sows. J. Am. Vet. Med. Assoc. 208, 1058-1062, 1996.

6. Engblom L., Lundeheim N., Dalin A-M., Andersson K.: Sow removal in Swedish commercial herds. Livest. Sci. 106, 76-86, 2007.

7. Engblom L., Lundeheim N., Strandberg E., Schneider M.P., Dalin A.M., Andersson K.: Factors affecting length of productive life in Swedish commercial sows. J. Anim. Sci. 86, 432-441, 2008.

8. Friendship C.R., Bilkei G.: Concurrent swine erysipelas and Clostridium novyi infections associated with sow mortality in outdoor sows in Kenya. Veterinary Journal, 173, 3, 694-696, 2007.

9. Jandowsky A., Bodenthin A., Seyboldt C., Frolich K.: Sudden death of outdoor housed pigs caused by Clostridium novyi. Tieraerztliche Praxis Ausgabe Grosstiere Nutztiere, 41, 6, 392-395, 2013.

10. Jensen T.B., Toft N., Bonde M.K., Kongsted A.G., Kristensen A.R., Sørensen J.T.: Herd and sow-related risk factors for mortality in sows in group-housed systems. Preventive veterinary medicine, 103, 1, 31-37, 2012.

11. Kim I-H., Suh G-H.: Effect of the amount of body condition loss from the dry to near calving periods on the subsequent body condition change, occurrence of portpartum diseases, metabolic parameters and reproductive performance in Holstein dairy cows. Theriogenology, 60, 1445-1456, 2003.

12. Knauer M., Stalder K.J., Karriker L., Baas T.J., Johnson C., Serenius T., Layman L., McKean J.D.: A descriptive survey of lesions from cull sows harvested at two Midwestern U.S. facilities. Prev. Vet. Med. 82, 198-212, 2007.

13. Koketsu Y.: Six component intervals of nonproductive days by breedingfemale pigs on commercial farms. J. Anim. Sci. 83, 1406-1412, 2005.

14. Koketsu, Y.: Retrospective analysis of trends and production factors associated with sow mortality on swine-breeding farms in USA. Prev. Vet. Med. 46, 249-256, 2000.

15. Quinn P.J., Carter M.E., Markey B.K., Carter G.R.: Clinical Veterinary Microbiology. Mosby International, Linton House, London, 1998.

16. Sasaki Y., Koketsu Y.: Mortality, death interval, survivals, and herd factors for death in gilts and sows in commercial breeding herds. J. Anim. Sci. 86, 3159-3165, 2008.

17. Scott K., Binnendijk G.P., Edwards S.A., Guy J.H., Kiezebrink M.C., Vermeer H.M.: Preliminary evaluation of a prototype welfare monitoring system for sows and piglets (Welfare Quality ${ }^{\circledR}$ project). Anim. Welf. 18, 441-449, 2009. 
18. Stojanac N., Stevančević O., Potkonjak A., Kovačević Z., Toholj B., Ljubojević D., Kragić S.: Seroprevalence of infectious causes of abortion in sows. Contemporary Agriculture, 62, 3-4, 206-211, 2013.

19. Vestergaard K., Bækbo P., Svensmark B.: Sow mortality and causes for culling of sows in Danish pig herds. In: Proceedings of the 19th International Pig Veterinary Society Congress, Copenhagen, Denmark, 2006, p. 255.

Primljeno: 10.02.2014.

Odobreno: 08.07.2014. 